\title{
LACK OF ST2 ENHANCES HIGH-FAT DIET-INDUCED VISCERAL ADIPOSITY AND INFLAMMATION IN BALB/c MICE
}

Jelena M. Pantic ${ }^{1}$, Nada N. Pejnovic ${ }^{1,2}$, Gordana D. Radosavljevic ${ }^{1}$, Ivan P. Jovanovic ${ }^{1}$, Aleksandar LJ. Djukic ${ }^{2,3}$, Nebojsa N. Arsenijevic ${ }^{1}$, and Miodrag L. Lukic ${ }^{1}$

${ }^{1}$ Center for Molecular Medicine and Stem Cell Research, Faculty of Medical Sciences, University of Kragujevac, Serbia;

${ }^{2}$ Institute of Pathophysiology, Faculty of Medical Sciences, University of Kragujevac, Serbia;

${ }^{3}$ Center for Endocrinology, Diabetes, and Metabolic Diseases, Clinical Center Kragujevac, Serbia.

\section{DELECIJA GENA ZA ST2 PROMOVIŠE GOJAZNOST I INFLAMACIJU U VISCERALNOM ADIPOZNOM TKIVU BALB/C MIŠEVA \\ NA DIJETI SA VISOKIM SADRŽAJEM MASTI \\ Jelena M. Pantić ${ }^{1}$, Nada N. Pejnović ${ }^{1,2}$, Gordana D. Radosavljević ${ }^{1}$, Ivan P. Jovanović ${ }^{\text {, }}$ \\ Aleksandar LJ. Djukić ${ }^{2,3}$, Nebojsa N. Arsenijević ${ }^{1}$, and Miodrag L. Lukić ${ }^{1}$ \\ ${ }^{1}$ Centar za molekulsku medicinu i istraživanja matičnih ćelija, Fakultet medicinskih nauka, Univerzitet u Kragujevcu, \\ ${ }^{2}$ Institut za patofiziologiju, Fakultet medicinskih nauka, Univerzitet u Kragujevcu, \\ ${ }^{3}$ Centar za endokrinologiju, dijabetes i bolesti metabolizma, Klinički centar Kragujevac, Srbija}

Received / Primljen: 26.12.2013.

Accepted / Prihvaćen: 16.01.2014.

\section{ABSTRACT}

Obesity and obesity-related disorders are strongly associated with a chronic low-grade inflammation that originates from growing visceral adipose tissue during nutrient excess. Although interleukin (IL)-33 may play a protective role in obesity and atherosclerosis, the impact of the IL-33/ST2 axis on metabolic disorders needs to be further elucidated.

In this study, we investigated the role of the IL-33/ST2 pathway in high-fat diet (HFD)-induced obesity using ST2deficient (ST2 $\left.{ }^{-/}\right)$and wild type BALB/c mice.

The deletion of ST2 enhanced systemic and visceral adipose tissue (VAT) inflammation; ST2\% mice that were fed a HFD for 18 weeks had experienced a significantly increased weight gain and had a higher amount of total VAT. More classically activated M1 macrophages and markedly fewer alternatively activated M2 macrophages were observed in the VAT of the HFD-fed ST2- mice. Additionally, the VAT of the HFD-fed ST2 ${ }^{-1-}$ mice had an increased percentage of $\mathrm{CD}^{+} \mathrm{T}$ cells but fewer $\mathrm{CD} 4^{+} \mathrm{CD} 25^{+} \mathrm{FoxP} 3^{+} \mathrm{T}$ regulatory cells when compared to the VAT of the low-fat diet-fed controls. The numbers of $C D 3^{+} I L-17^{+}$and IL-5 positive VATderived mononuclear cells were significantly decreased in the HFD-fed ST2 $2^{-1}$ mice. Serum levels of the proinflammatory cytokines IL-1 $\beta$ and IFN- $\gamma$ were increased in the HFDfed ST2 $\%$ mice, while the levels of IL-6 and CRP did not differ among the groups. Importantly, the levels of the antiinflammatory cytokines $I L-10$ and $I L-13$ were significantly lower in the sera of the ST2 $2^{-}$mice than the levelsin the sera of the wild-type controls.

Our findings suggest a protective role of IL33/ST2 signalling in high-fat diet-induced adipose tissue inflammation. ST2 deficiency related to nutrient excess is associated with the polarisation of macrophages toward the M1 phenotype and the induction of a Th1-mediated immune response.

Key words: obesity, adipose tissue, inflammation, cytokines, macrophages

\section{SAŽETAK}

Uosnovi patogeneze gojaznosti i metaboličkih poremećaja povezanih sa gojaznošću je hronična sistemska inflamacija niskog stepena koja nastaje u visceralnom adipoznom tkivu (VAT) u uslovima povećanog unosa nutrijenata. Iako rezultati dosadašnjih istraživanja ukazuju na moguću protektivnu ulogu IL-33 u nastanku gojaznosti $i$ ateroskleroze, uloga IL-33/ST2 signalnog puta u patogenezi ovih bolesti je nedovoljno razjašnjena.

U ovom istraživanju ispitivali smo ulogu IL-33/ST2 signalnog puta u mišjem modelu gojaznosti indukovane primenom dijete sa visokim sadržajem masti u ST2 deficijentnih $i$ miševima divljeg soja $B A L B / c$.

Delecija gena za ST2 promoviše sistemsku inflamaciju i inflamaciju u VAT-u što se ogleda u porastu telesne mase $i$ uvećanju količine VAT-a tokom 18 nedelja primene dijete sa visokim sadržajem masti. Proinflamatorni milje u VAT-u ST2-1- miševa na ishrani bogatoj mastima karakteriše povećana zastupljenost klasično aktiviranih M1 makrofaga, uz smanjeno prisustvo alternativno aktiviranih M2 makrofaga. Pored toga, dijeta sa visokim sadržajem masti značajno je uticala na povećanje zastupljenosti $\mathrm{CD}^{+} \mathrm{T}$ limfocita, dok je prisustvo $\mathrm{CD} 4^{+} \mathrm{CD} 25^{+} \mathrm{FoxP3^{+ }}$ regulatornih $T$ limfocita bilo značajno sniženo u VAT-u ST2-miševa u odnosu na ST2-- miševe na dijeti sa niskim sadržajem masti. Učestalost CD $3^{+} I L-17^{+}$i IL-5 pozitivnih mononuklearnih ćelija je bila značajno smanjena u VAT-u gojaznih ST2-- miševa. Iako nije bilo razlike u serumskim nivoima IL-6i CRP-a, koncen-

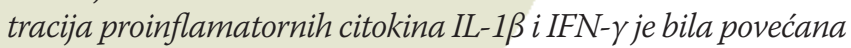
u gojaznih ST2-- miševa. Važno je istaći da su serumski nivoi anti-inflamatornih citokina, IL-10 i IL-13, bili niži u ST2-- miševa u poređenju sa miševima divljeg soja.

Rezultati studije ukazuju na protektivnu ulogu IL-33/ ST2 signalnog puta u pokretanju inflamacije u VAT-u nakon primene dijete sa visokim sadržajem masti, koju karakteriše polarizacija makrofaga u pravcu M1 fenotipa i indukcija Th1 imunskog odgovora.

Ključne reči: gojaznost, adipozno tkivo, inflamacija, citokini, makrofagi 


\section{ABBREVIATIONS}

BSA-bovine serum albumin CRP-C reactive protein

CD-cluster of differentiation FBS-foetal bovine serum FoxP3- forkhead box P3 HFD-high-fat diet IL-interleukin
LFD-low-fat diet

NKT-natural killer T cells

PBS-phosphate-buffered saline

Th-T helper cells

TNF- $\alpha$-tumour necrosis factor- $\alpha$

WT- wild-type

VAT-visceral adipose tissue

IFN- $\boldsymbol{\gamma}$-interferon- $\boldsymbol{\gamma}$

\section{INTRODUCTION}

The complex pathogenesis of obesity and obesity-related metabolic disorders are strongly associated with a chronic low-grade inflammation that is characterizised by an increased recruitment of immune cells into the visceral adipose tissue (VAT) [1]. Adipocytes are believed to play a central role in the initiation of the inflammatory response in response to metabolic danger signals during increased caloric intake [2]. The expanding adipose tissue found in obese individuals is predominantly infiltrated with IFN- $\gamma$ producing Th1 and NKT cells, followed by an enhanced recruitment of classically activated M1 macrophages with a related decrease in the presence of alternatively activated M2 macrophages [3-6]. Activated macrophages produce pro-inflammatory cytokines, such as IL-1 $\beta$, IL-6 and TNF- $\alpha$, which contribute to systemic inflammation and negatively impact insulin sensitivity [7]. This proinflammatory milieu resulting from nutrient excess is additionally characterised by a significantly decreased presence of immunosuppressive regulatory $\mathrm{T}$ cells in the visceral adipose tissue [8].

IL-33 is a newly identified member of the IL-1 cytokine family, which includes IL-1 and IL-18 [9]. Several lines of evidence suggest that IL-33 is a pleiotropic cytokine that signals through its receptor ST2 to orchestrate the innate and acquired immune responses [10]. Although IL-33 is primarily involved in the induction of Th2-type responses and can act directly on Th2 cells to increase the secretion of Th2 cytokines, such as IL-5 and IL-13, IL-33 can also promote Th1-type responses under certain conditions $[11,12]$. Additionally, IL-33 induces the production of proinflammatory cytokines and chemokines by mast cells and eosinophils and amplifies the polarisation of alternatively activated M2 macrophages [13].

IL-33 is a multifunctional cytokine involved in the pathogenesis of not only different inflammatory and autoimmune diseases, as well as in the pathogenesis of carcinogenesis [14-17]. Although IL-33 may play a protective role in obesity and atherosclerosis [18,19], the contribution of the IL-33/ST2 axis in metabolic disorders needs to be further elucidated. Aware that the BALB/c mice are relatively resistant to HFDhigh-fat diet (HFD)-induced obesity, we investigated the role of ST2 in HFD-induced obesity using ST2 deficient $\left(\mathrm{ST}^{-/-}\right)$and wild-type BALB/c mice.

\section{MATERIAL AND METHODS}

\section{Animals}

Six-week-old, male ST2 deficient $\left(\mathrm{ST}^{-{ }^{--}}\right)$and corresponding wild-type (WT) BALB/c mice were fed either a high-fat diet (HFD with 60\% fat, obtained from Mucedola, Milan, Italy) or a low-fat diet (LFD with $3 \%$ fat, obtained from Mucedola, Milan, Italy) and were given free access to food and water. After 18 weeks on the specific diets, the animals were sacrificed, and the targeted tissues were collected for further examination. Blood collected from the abdominal aorta was centrifuged, and the isolated sera were stored at $-20^{\circ} \mathrm{C}$ until further analysis. All animal procedures were approved by the Ethical Committee of the Faculty of Medical Sciences at the University of Kragujevac.

\section{Metabolic parameters}

Body weight and fasting blood glucose levels were measured every second week of the month. To evaluate fortest for glycaemia, whole blood was collected via tail vein puncture and assessed using the Accu-Chek glucometer (Roche Diagnostics, Mannheim, Germany). The total visceral adipose tissue was isolated from the peritoneal cavity and measured after sacrifice.

\section{Isolation of mononuclear cells from \\ the visceral adipose tissue}

The visceral adipose tissue was minced and washed twice in PBS containing $10 \%$ FBS. The tissue was then digested with $1 \mathrm{mg} / \mathrm{ml}$ collagenase type II (Sigma-Aldrich, St. Louis, MO, USA) in PBS containing 2\% BSA for $1 \mathrm{~h}$ at $37^{\circ} \mathrm{C}$ with vigorous shaking. The digested tissue was passed through a $40 \mu \mathrm{m}$ nylon cell strainer (BD Biosciences, San Jose, CA, USA), and the red blood cells were lysed using an erythrocyte lysis buffer. The isolated cells were then washed twice and resuspended in a RPMI cell medium (Sigma-Aldrich) containing 10\% FBS for flow cytometric analysis.

\section{Flow cytometry}

The cells were labelled with the following fluorochromeconjugated monoclonal antibodies: anti-mouse CD3, CD4, IL-17, IL-5, CD25, FoxP3, F4/80, CD206 and CD11c (all from $\mathrm{BD}$ Biosciences). For intracellular staining, the cells were activated using PMA (50 ng/ml) and ionomycin (500 $\mathrm{ng} / \mathrm{ml}$ ) (Sigma-Aldrich) with GolgyStop (BD Biosciences) 
for $5 \mathrm{~h}$ at $37^{\circ} \mathrm{C}$ and then stained with the fluorochromeconjugated antibodies using the Cytofix/Cytoperm kit (BD Biosciences) according to the manufacturer's protocol. The cells were analysed using a FACS Calibur flow cytometer (BD Biosciences), and the analysis was conducted with the FlowJo software (Tree Star).

\section{Serum cytokines measurement}

The sera were assayed for CRP, IL- $1 \beta$, IL-6, IFN- $\gamma$, IL10 and IL-13 using highly sensitive enzyme-linked immunosorbent assay (ELISA) kits (R\&D Systems, Minneapolis, MN, USA) that were specific for these mouse cytokines; the kits were used in accordance with the manufacturer's instructions.

\section{Statistical analysis}

All data are presented as the mean \pm SE. The data were analysed with the statistical package SPSS, version 13, by using either a two-tailed Student's t-test or the nonparametric Mann-Whitney test, where appropriate. The results were considered significantly different when $\mathrm{p}<0.05$.
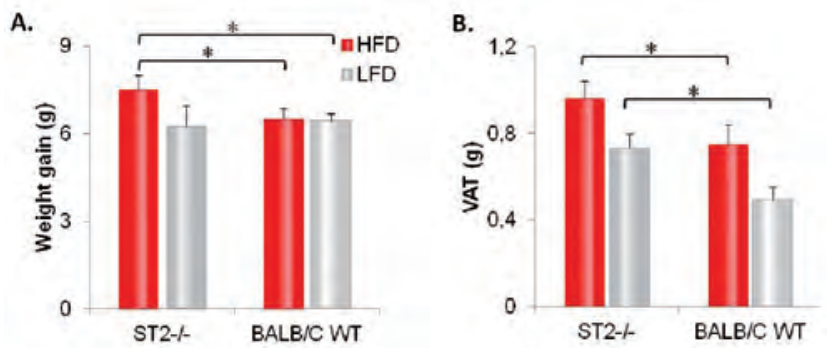

C.
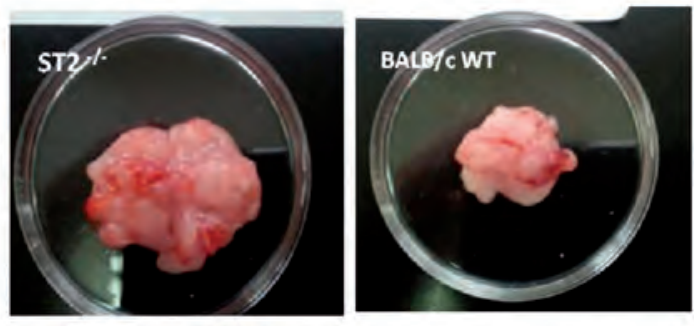

HFD
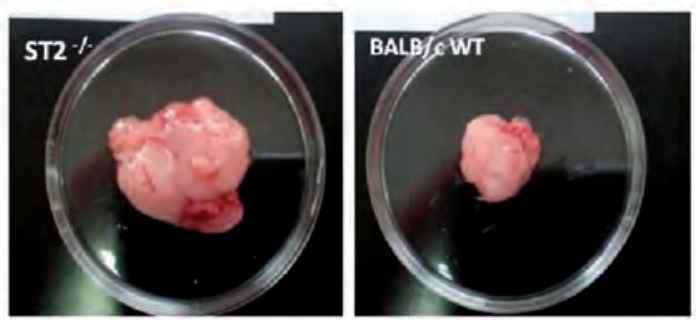

Figure 1. Increased visceral adiposity in HFD-fed ST2 deficient mice. A. Total weight gain was individually determined for each mouse after 18 weeks on the specific diet regimens. B. Total visceral adipose tissue was excised and measured after sacrifice, which occurred 18 weeks after the mice began the specific diet regimens. C. Representative photographs of isolated visceral adipose tissue after sacrifice. The data are presented as the mean \pm SE. Statistical significance was determined at $* \mathrm{p}<0.05$.

\section{RESULTS}

Deletion of ST2 accelerates HFD-induced adiposity

After 18 weeks on the specific diets, we observed a significant weight gain in the HFD-fed ST2 $2^{-1-}$ mice compared to the WT mice on both diet regimes. Total weight gain was determined as the difference in body weight of each mouse after 18 weeks on a specific diet and the body weight measured on day 0 . The body weight did not differ among the groups on day 0 (data not shown). Our data showed that the HFD-fed ST2 deficient mice had a significantly increased total weight gain during the 18 weeks when compared to both the HFD-fed and the LFD-fed WT mice (Figure 1A). We also observed a significantly larger amount of total visceral adipose tissue in the HFD-fed ST2 ${ }^{-1-}$ mice than in the corresponding WT animals (Figure 1B, 1C). At the same time, the amount of total visceral adipose tissue isolated from the LFD-fed ST2 deficient mice was significantly higher than that isolated from the LFD-fed WT mice, indicating the relevance of the ST2 molecule in the expansion of the visceral adipose tissue (Figure 1B, 1C).

The adipose tissue of obese $\mathrm{ST} 2^{-/-}$mice have an increased percentage of $\mathrm{CD}^{+} \mathrm{T}$ cells , fewer $\mathrm{CD} 3^{+} \mathrm{IL}-17^{+}$and IL-5 expressing mononuclear cells and decreased regulatory $\mathrm{T}$ cells than the adipose tissue of $\mathrm{ST}^{-/-}$lean mice

Flow cytometric analysis of mononuclear cells isolated from the visceral adipose tissue showed that the HFD increased the infiltration of $\mathrm{CD}^{+} \mathrm{T}$ cells into the visceral adipose tissue of the ST2 deficient mice, and these cells expressed lower levels of IL-17 than those of the HFD-fed WT mice and
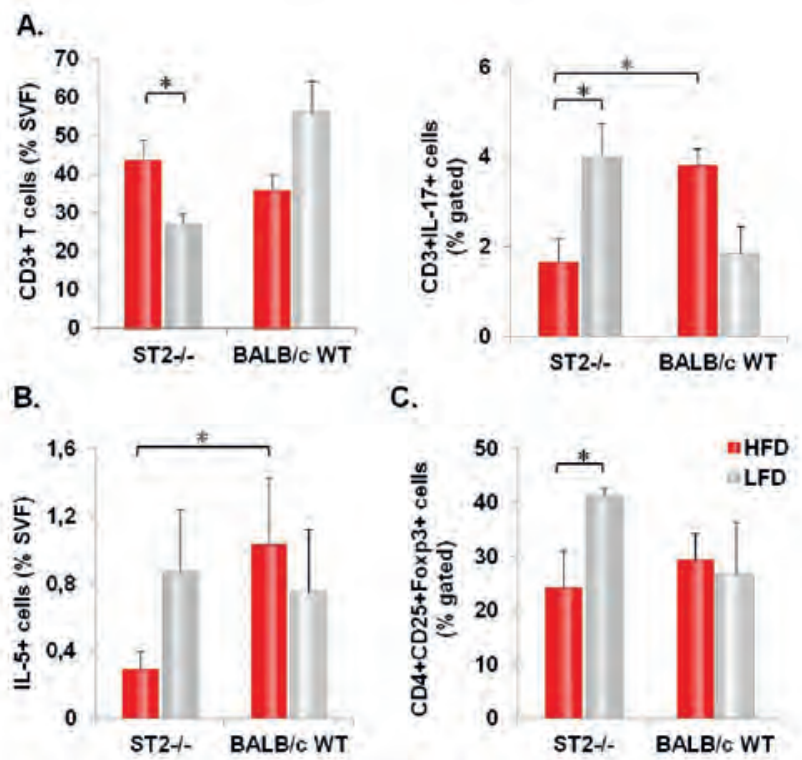

C.

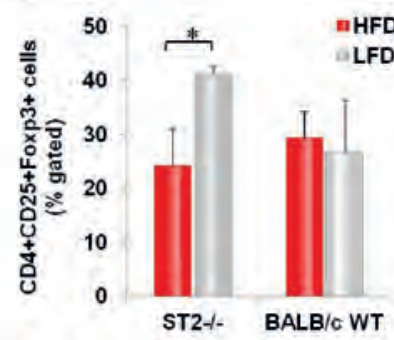

Figure 2. A higher percentage of $T$ cells and a decreased presence of IL-17-producing CD3+ cells, IL-5-positive mononuclear cells and regulatory $T$ cells in the VAT of HFD-fed ST2-/- mice. Mononuclear cells isolated from visceral adipose tissue were labelled with fluorochrome-conjugated anti-mouse antibodies and analysed with flow cytometry. The presence of different cell phenotypes was determined as a percentage of the gated mononuclear cells. The data are presented as the mean \pm SE. Statistical significance was determined at ${ }^{*} \mathrm{p}<0.05$. 
A.

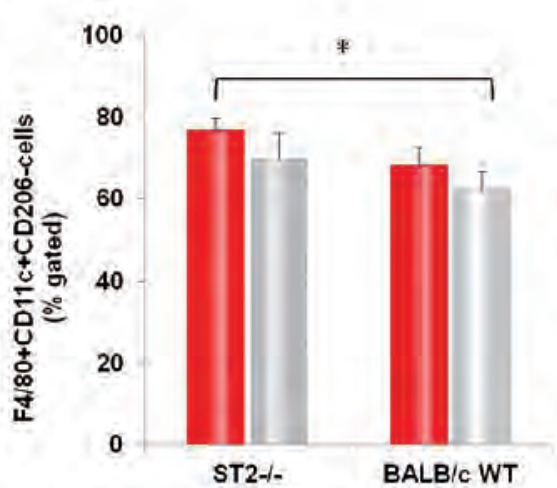

B.

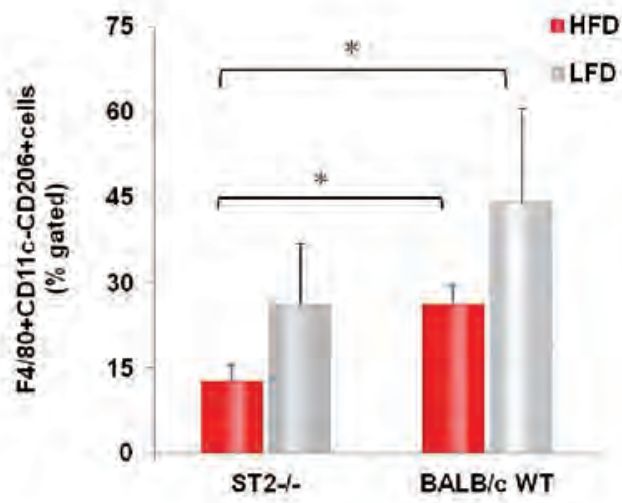

Markedly reduced alternatively activated M2 macrophages in the VAT of obese ST2 ${ }^{-1-}$ mice

To further understand obesity-related inflammation in the studied mice after 18 weeks, we investigated the recruitment of macrophages into the visceral adipose tissue and analysed their phenotypes. The number of the proinflammatory $\mathrm{F} 4 / 80^{+} \mathrm{CD} 11 \mathrm{c}^{+} \mathrm{CD} 206^{+}$ macrophages was significantly increased in the HFD-fed ST2 deficient mice when compared

Figure 3. A decreased percentage of alternatively activated M2 macrophages in the HFD-fed ST2-/- mice. The frequencies of different cell phenotypes are presented as percentages of the gated mononuclear cells isolated from visceral adipose tissue using a collagenase digestion protocol. The isolated cells were labelled with fluorochrome-conjugated anti-mouse antibodies and analysed using flow cytometry. The data are presented as the mean \pm SE. Statistical significance was determined at * $\mathrm{p}<0.05$.

the LFD-fed ST2 ${ }^{-/}$mice (Figure 2A). The number of IL-5producing mononuclear cells was significantly decreased in the visceral adipose tissue of the HFD-fed ST2 $\%$ mice compared to the number in the corresponding WT animals (Figure $2 \mathrm{~B}$ ). The presence of $\mathrm{CD} 4{ }^{+} \mathrm{CD} 25^{+} \mathrm{FoxP} 3^{+}$regulatory $\mathrm{T}$ cells in the visceral adipose tissue was significantly reduced in the ST2 deficient mice after HFD feeding (Figure 2C).
A.

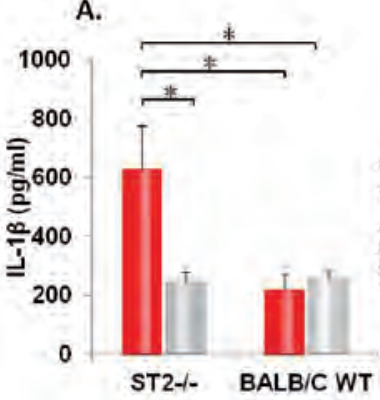

c.

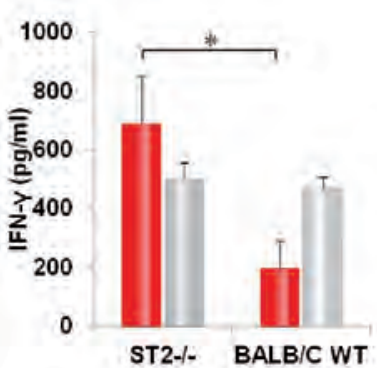

B.

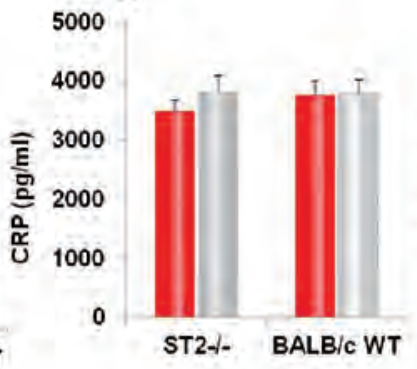

D.

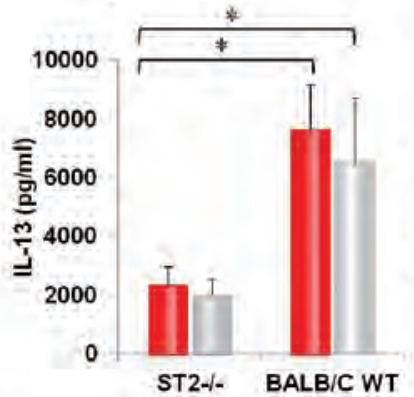

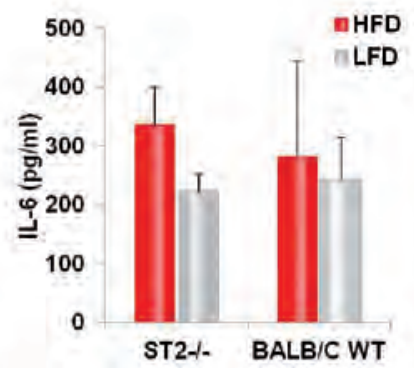

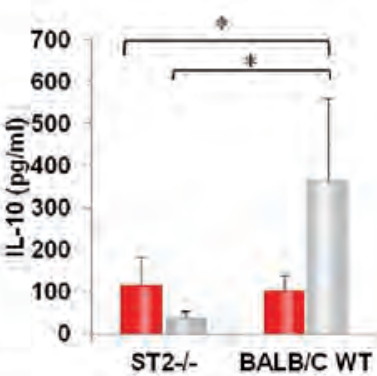

withto the LFD-fed WT mice (Figure 3A), but this number was not increased compared to the other experimental groups. However, the number of alternatively activated $\mathrm{F} 4 / 80^{+} \mathrm{CD} 11 \mathrm{C}^{-} \mathrm{CD} 206^{+} \mathrm{M} 2$ macrophages was markedly reduced in the visceral adipose tissue of the HFD-fed ST2 ${ }^{-1-}$ mice in comparison with both the diet-matched WT animals and the LFD-fed WT mice (Figure 3B).

Obese $\mathrm{ST}^{-/-}$mice have increased serum levels of the proinflammatory IL-1 $\beta$ and IFN- $\gamma$ and lower levels of the anti-inflammatory IL-13 and IL-10

The systemic inflammatory profile of the experimental mice was evaluated by measuring the serum cytokine levels. After 18 weeks on a HFD, the ST2 deficient mice had exhibited markedly elevated levels of the proinflammatory cytokine IL- $1 \beta$ than compared to the diet-matched WT mice and the LFD-fed mice of both genotypes (Figure 4A). At the same time, we did not observe any difference in the serum levels of the C-reactive protein (CRP) and IL- 6 among the experimental groups (Figure 4B). However, the serum level of IFN- $\gamma$ was significantly increased in the HFD-fed ST2 $\%$ mice thancompared to in the corresponding WT mice (Figure 4C). After 18 weeks on the specific diet, both the ST2 deficient mice on the HFD and LFD had a significantly lower systemic levels of IL-13 when compared to the $\mathrm{WT}$ mice on the respective

Figure 4. Increased levels of the proinflammatory cytokines IL- $\beta$ and IFN- $\gamma$ and decreased levels of the anti-inflammatory cytokines IL-13 and IL-10 in the sera of obese ST2 deficient mice. The levels of cytokines in the serum were measured for each mouse after 18 weeks on the different diet regimens using specific ELISA tests. The data are presented as the mean \pm SE. Statistical significance was determined at "p $<0.05$. diets; additionally, both the HDF-fed and LDF-fed ST2 deficient mice exhibited decreased production of the antiinflammatory IL-10 than compared to the LFD-fed WT mice (Figure 4D). 


\section{DISCUSSION}

In this study, we showed that the ablation of ST2 enhances the visceral adiposity of HFD-fed mice, as indicated by a significant increase in weight and a growing amount of visceral adipose tissue. The amount of VAT was significantly increased in both the HFD-fed ST2 ${ }^{-1-}$ mice and the LFD-fed ST2 ${ }^{-/-}$mice compared to their diet-matched WT counterparts. The enhanced adiposity of the ST2 deficient mice was characterised by an increased presence of $\mathrm{CD}^{+} \mathrm{T}$ cells, which is in line with previously reported data showing that the infiltration of $\mathrm{T}$ cells into the visceral adipose tissue and their polarisation toward a Th1 phenotype played a crucial role in high-fat diet-induced obesity $[3,20]$. The induction of Th2 cytokine production is a well-established result of the interaction between IL-33 and the ST2 receptor [11]. Multiple cell types, including the adipocytes in the visceral adipose tissue, can most likely produce IL-33, resulting into the maintenance of tissue homeostasis by promoting a Th2 immune response and the production of Th2 cytokines, such as IL-4, IL-5 and IL-13 [21]. According to those findings, a HFD resulted in a significantly decreased the percentage of IL-5 positive mononuclear cells in the VAT of ST2-deficient mice compared to the HFD-fed WT mice. Interestingly, our data showed a significantly lower incidence of IL-17-producing $\mathrm{CD}^{+}$cells in the HFD-fed ST2 knockout mice in contrast to the corresponding WT mice and the LFD-fed ST2 deficient mice. Although there is evidence that IL-17 may be a negative regulator of adipose tissue inflammation [22], the decreased expression of IL-17 could be related to the enhanced Th1 immune response duringin obesity [23].

There is evidence that regulatory $\mathrm{T}$ cells play an important role in the maintenance of adipose tissue homeostasis and glucose sensitivity [24]. During diet-induced inflammation, the presence of $\mathrm{T}$ regulatory cells in the visceral adipose tissue decreases [8], which is in line with our findings that a HFD significantly reduced the incidence of $\mathrm{CD}^{+} \mathrm{CD} 25^{+} \mathrm{FoxP} 3^{+}$ regulatory $\mathrm{T}$ cells in the ST2 deficient mice.

The polarizisation of infiltrated macrophages toward the classically activated M1 phenotype and a significant reduction in the amount of alternatively activated M2 macrophages is the mechanism underlies the diet-induced inflammation in the visceral adipose tissue [6]. However, IL-33 promotes the phenotypic switch of macrophages to an M2 phenotype during in obesity [18]. We found that the lack of the IL-33 receptor ST2 expression is correlated with the markedly increased presence of the F4/80+CD11 ${ }^{+} \mathrm{CD} 206^{+} \mathrm{M} 1$ macrophages in the visceral adipose tissue of the HFD-fed mice. These M1 macrophages were recently described as the proinflammatory cell subset present duringin diet-induced obesity [25]. At the same time, we found a significantly decreased incidence of the alternatively activated $\mathrm{F} 4 / 80^{+} \mathrm{CD} 11 \mathrm{c}^{-} \mathrm{CD} 206^{+}$ M2 macrophages, which is in line with a previous report related to the phenotypic switch of macrophages in dietinduced obesity in mice [26].
Accelerated HFD-induced adiposity in the absence of ST2 was associated with increased systemic levels of proinflammatory cytokines, such as IL-1 $\beta$ and IL-6 [7], and decreased levels of the anti-inflammatory cytokines IL-13 and IL-10 [27, 28]. Although we did not find any differences in the production of IL- 6 and CRP between the experimental groups, the systemic level of the proinflammatory IL-1 $\beta$ was significantly increased in the HFD-fed ST2 deficient mice than in the other experimental groups. In the absence of IL33/ST2 signalling, we observed significantly decreased levels of the anti-inflammatory cytokines IL-13 and IL-10, which were strongly correlated with the enhanced obesity in the ST2 deficient mice.

\section{CONCLUSIONS}

These findings suggest that IL33/ST2 signalling plays an important protective role in high-fat diet-induced adipose tissue inflammation and could be of therapeutic relevance.

\section{ACKNOWLEDGMENTS}

This work was funded by grants from the Serbian Ministry of Science and Technological Development (Grants No. 175071 and 175069), Serbia and The Faculty of Medical Sciences, University of Kragujevac (JP 03-11).

No potential conflicts of interest relevant to this article were reported.

\section{REFERENCES:}

1. Hotamisligil GS. Inflammation and metabolic disorders. Nature 2006; 444:860-7.

2. Lumeng CN, Saltiel AR. Inflammatory links between obesity and metabolic disease. J Clin Invest 2011; 121:2111-17.

3. Strissel KJ, DeFuria J, Shaul ME, Bennett G, Greenberg AS, Obin MS. T-cell recruitment and Th1 polarization in adipose tissue during diet-induced obesity in C57BL/6 mice. Obesity (Silver Spring) 2010; 18:1918-25.

4. Ohmura K, Ishimori N, Ohmura Y, et al. Natural killer $\mathrm{T}$ cells are involved in adipose tissues inflammation and glucose intolerance in diet-induced obese mice. Arterioscler Thromb Vasc Biol 2010; 30:193-9.

5. Pejnovic N, Pantic J, Jovanovic I, et al. Galectin-3 deficiency accelerates high-fat diet induced obesity and amplifies inflammation in adipose tissue and pancreatic islets. Diabetes 2013; 62:1932-44.

6. Lumeng CN, Bodzin JL, Saltiel AR. Obesity induces a phenotypic switch in adipose tissue macrophage polarization. J Clin Invest 2007; 117:175-84.

7. Xu H, Barnes GT, Yang Q, et al. Chronic inflammation in fat plays a crucial role in the development of 
obesity-related insulin resistance. J Clin Invest 2003; 112(12):1821-30.

8. Feuerer M, Herrero L, Cipolletta D, et al. Lean, but not obese, fat is enriched for a unique population of regulatory $\mathrm{T}$ cells that affect metabolic parameters. Nat Med 2009; 15:930-9.

9. Liew FY, Pitman NI, McInnes IB. Disease-associated function of IL-33: the new kid in the IL-1 family. Nat Rev Immunol 2010; 10:103-10.

10. Chackerian AA, Oldham ER, Murphy EE, Schmitz J, Pflanz S, Kastelein RA. IL-1 receptor accessory protein and ST2 comprise the IL-33 receptor complex. J Immunol 2007; 179:2551-5.

11. Schmitz J, Owyang A, Oldham E, et al. IL-33, an interleukin-1-like cytokine that signals via the IL-1 receptor-related protein ST2 and induces T helper type 2-associated cytokines. Immunity 2005; 23:479-90.

12. Bourgeois E, Van LP, Samson M, et al. The pro-Th2 cytokine IL-33 directly interacts with invariant NKT and NK cells to induce IFN- $\gamma$ production. Eur J Immunol 2009; 39:1046-55.

13. Kurowska-Stolarska M, Stolarski B, Kewin P, et al. IL33 amplifies the polarization of alternatively activated macrophages that contribute to airway inflammation. J Immunol 2009; 183:6469-77.

14. Volarevic V, Mitrovic M, Milovanovic M, et al. Protective role of IL-33/ST2 axis in Con A-induced hepatitis. J Hepatol 2012; 56:26-33.

15. Milovanovic M, Volarevic V, Ljujic B, et al. Deletion of IL-33R (ST2) Abrogates Resistance to EAE in BALB/C Mice by Enhancing Polarization of APC to Inflammatory Phenotype. PLoS One 2012; 7 (9):e45225.

16. Zdravkovic N, Shahin A, Arsenijevic N, Lukic ML, Mensah-Brown EP. Regulatory T cells and ST2 signaling control diabetes induction with multiple low doses of streptozotocin. Mol Immunol 2009; 47(1):28-36.

17. Jovanovic I, Radosavljevic G, Mitrovic M, et al. ST2 Deletion Enhances Innate and Acquired Immunity to Murine Mammary Carcinoma. Eur J Immunol 2011; 41:1902-12.
18. Miller AM, Asquith DL, Hueber AJ, et al. Interleukin-33 Induces Protective Effects in Adipose Tissue Inflammation During Obesity in Mice. Circ Res 2010; 107:650-8.

19. Miller AM, Xu D, Asquith DL, et al. IL-33 reduces the development of atherosclerosis. J Exp Med 2008; 205:339-46.

20. Kintscher U, Hartge M, Hess K, et al. T-lymphocyte infiltration in visceral adipose tissue: a primary event in adipose tissue inflammation and the development of obesity-mediated insulin resistance. Arterioscler Thromb Vasc Biol 2008; 28:1304-10.

21. Kang K, Reilly SM, Karabacak V, et al. Adipocyte-derived Th2 cytokines and myeloid PPARdelta regulate macrophage polarization and insulin sensitivity. Cell Metab 2008; 7:485-95.

22. Zuniga LA, Shen WJ, Joyce-Shaikh B, et al. IL-17 Regulates Adipogenesis, Glucose Homeostasis, and Obesity. J Immunol 2010; 185:6947-59.

23. Zorzanelli Rocha V, Folco EJ, Sukhova G, et al. Interferon- $\gamma$, a Th1 Cytokine, Regulates Fat Inflammation A Role for Adaptive Immunity in Obesity. Circ Res 2008; 103:467-76.

24. Ilan Y, Maron R, Tukpah AM, et al. Induction of regulatory $\mathrm{T}$ cells decreases adipose inflammation and alleviates insulin resistance in ob/ob mice. Proc Natl Acad Sci USA 2010; 107:9765-70.

25. Nguyen MTA, Favelyukis S, Nguyen A-K, et al. A subpopulation of macrophages infiltrates hypertrophic adipose tissue and is activated by free fatty acids via Tolllike receptors 2 and 4 and JNK-dependent pathways. J Biol Chem 2007; 282:35279-92.

26. Fujisaka S, Usui I, Bukhari A, et al. Regulatory mechanisms for adipose tissue M1 and M2 macrophages in diet-induced obese mice. Diabetes 2009; 58:2574-82.

27. Hong EG, Ko HJ, Cho YR, et al. Interleukin-10 prevents diet-induced insulin resistance by attenuating macrophage and cytokine response in skeletal muscle. Diabetes 2009; 58:2525-35.

28. Stanya KJ, Jacobi D, Liu S, et al. Direct control of hepatic glucose production by interleukin-13 in mice. J Clin Invest 2013; 123:261-71. 